\title{
PARAQUAT-INDUCED MODEL OF PARKINSON'S DISEASE AND DETECTION OF PHOSPHORYLATED $\alpha$-SYNUCLEIN IN THE ENTERIC NERVOUS SYSTEM OF RATS
}

Stavrovskaya AV $\bowtie$, Voronkov DN, Kutukova KA, Ivanov MV, Gushchina AS, Illarioshkin SN

Research Center of Neurology, Moscow, Russia

Parkinson's disease (PD) is a common neurodegenerative disorder with a variety of motor and non-motor features. Non-motor symptoms, such as gastrointestinal dysfunction, usually set in 5 to 15 years earlier than motor manifestations. Cytoplasmic aggregates of phosphorylated $\alpha$-synuclein are a typical marker of PD. They are observed not only in cerebral neurons but also in intramural plexuses of the intestine. Therefore, it is essential to investigate the peripheral component of the molecular pathogenesis of the disease using PD models, including those involving the use of parkinsonian neurotoxins, such as the well-known herbicide paraquat. The aim of this study was to identify a complex of early $\alpha$-synuclein-related changes induced by long-term systemic administration of paraquat to rats at doses of $6 \mathrm{mg} / \mathrm{kg}$. The open-field test revealed a decline in the motor activity of the experimental animals; the tapered beam walking test demonstrated a two-fold increase $(p=0.044)$ in the number of left paw slips. Besides, the intensity of staining for tyrosine hydroxylase (TH) in the substantia nigra and myenteric plexus fibers was $50 \%(p=0.033)$ and $20 \%(p=0.01)$ lower, respectively, in the main group than in the controls. Phosphorylated $\alpha$-synuclein content was increased in the cell bodies of myenteric neurons and in TH-positive nervous fibers of the experimental animals. Changes indicating the development of peripheral $\alpha$-synuclein pathology in the early stage of induced PD are similar to the changes observed in patients with PD at the onset of the disease. The proposed paraquat regimen could be very promising for PD modeling.

Keywords: Parkinson's disease, animal models, $\alpha$-synuclein, paraquat, behavior, tyrosine hydroxylase

Funding: this work supported by the Russian Science Foundation (Grant 19-15-00320).

Acknowledgement: the authors thank their colleagues, Olshansky AS and Yamshchikova NG (the Laboratory of Experimental Pathology of the Nervous System), for their valuable contribution.

Author contribution: Stavrovskaya AV planned the study, analyzed the literature, collected, analyzed and interpreted the obtained data, conducted behavioral tests, administered drugs to the animals, and prepared the draft of the manuscript; Voronkov DN analyzed the literature, analyzed and interpreted the obtained data, prepared brain slides, conducted the histopathologic examination, and prepared the draft of the manuscript; Kutukova KA analyzed the literature, analyzed the obtained data, prepared jejunum slides, carried out the histopathologic examination, and prepared the draft of the manuscript; Ivanov MV prepared jejunum slides and carried out the histopathologic examination; Gushchina AS collected data, administered drugs to the rats, carried out behavioral tests, and monitored the animals' health as a vet; Illarioshkin SN supervised the study and prepared the draft of the manuscript.

Compliance with ethical standards: the animals were treated and the experiments were conducted in full compliance with the Guide for the Care and Use of Laboratory Animals; the study was approved by the Ethics Committee of Research Center of Neurology (Protocol № 2-5/19 dated February 20, 2019).

$\triangle$ Correspondence should be addressed: Alla V. Stavrovskaya

per. Obukha 5, Moscow, 103064; alla_stav@mail.ru

Received: 12.08.2019 Accepted: 26.08.2019 Published online: 13.09.2019

DOI: $10.24075 /$ brsmu.2019.058

\section{ПАРАКВАТНАЯ МОДЕЛЬ ПАРКИНСОНИЗМА И ВЫЯВЛЕНИЕ ФОСФОРИЛИРОВАННОГО $\alpha$-СИНУКЛЕИНА В ЭНТЕРАЛЬНОЙ НЕРВНОЙ СИСТЕМЕ У КРЫС}

А. В. Ставровская ${ }^{\otimes}$, Д. Н. Воронков, К. А. Кутукова, М. В. Иванов, А. С. Гущина, С. Н. Иллариошкин

Научный центр неврологии, Москва, Россия

Болезнь Паркинсона (БП) - распространенное нейродегенеративное заболевание с широким спектром моторных и немоторных нарушений. Немоторные симптомы (в частности, нарушения функций желудочно-кишечного тракта) обычно опережают манифестацию нарушений моторики на 5-15 лет. Характерный признак БП, цитоплазматические агрегаты фосфорилированного белка $\alpha$-синуклеина, обнаруживают не только в церебральных нейронах, но и в интрамуральных вегетативных сплетениях кишечника. В связи с этим большое значение имеет оценка периферического звена молекулярного патогенеза БП на экспериментальных моделях, в том числе при воздействии специфических «паркинсонических» нейротоксинов, таких как гербицид паракват. Целью работы было выявить комплекс ранних патологических изменений, вовлекающих $\alpha$-синуклеин, при системном многократном введении крысам параквата в дозе 6 мг/кг. У экспериментальных животных было показано снижение двигательной активности в открытом поле, двукратное (p = 0,044) одностороннее увеличение числа случаев соскальзывания в тесте «сужающаяся дорожка», снижение интенсивности окрашивания на тирозингидроксилазу (ТирГд) структур черной субстанции среднего мозга и нервных волокон миентерального сплетения кишечника крысы на 50\% (p = 0,033) и на 20\% (p = 0,01) соответственно, а также увеличение содержания фосфорилированного $\alpha$-синуклеина в телах миентеральных нейронов и в ТирГд-позитивных волокнах. Полученные изменения, свидетельствующие о развитии периферической $\alpha$-синуклеинопатии на ранней стадии экспериментального паркинсонизма, сходнь с таковыми у пациентов в дебюте БП. Предложенный режим введения параквата может быть чрезвычайно перспективным в моделировании БП.

Ключевые слова: болезнь Паркинсона, моделирование на животных, $\alpha$-синуклеин, паракват, поведение, тирозингидроксилаза

Финансирование: работа поддержана грантом РНФ № 19-15-00320.

Благодарности: авторы благодарят сотрудников лаборатории экспериментальной патологии нервной системы А. С. Ольшанского и Н. Г. Ямщикову за вклад в работу.

Информация о вкладе авторов: А. В. Ставровская - планирование исследования, анализ литературы, сбор, анализ и интерпретация данных, введение препаратов, проведение поведенческих тестов, подготовка черновика рукописи; Д. Н. Воронков - анализ литературы, анализ и интерпретация данных, подготовка и проведение морфохимического исследования образцов мозга экспериментальных крыс, подготовка черновика рукописи; К. А. Кутукова анализ литературы, анализ данных, подготовка и проведение морфохимического исследования образцов тонкого кишечника экспериментальных крыс, подготовка черновика рукописи; М. В. Иванов - подготовка и проведение морфохимического исследования образцов тонкого кишечника экспериментальных крыс; А. С. Гущина - сбор данных, введение препаратов, проведение поведенческих тестов, ветеринарное сопровождение исследования; С. Н. Иллариошкин - общее руководство исследованием, подготовка черновика рукописи.

Соблюдение этических стандартов: содержание животных и проведение экспериментов с ними осуществляли в соответствии с международными правилами «Guide for the Care and Use of Laboratory Animals»; исследование одобрено этическим комитетом ФГБНУ НЦН (протокол № 2-5/19 от 20 февраля 2019 г.)

$\bowtie$ Для корреспонденции: Алла Вадимовна Ставровская пер. Обуха, д. 5, г. Москва, 103064; alla_stav@mail.ru

Статья получена: 12.08.2019 Статья принята к печати: 26.08.2019 Опубликована онлайн: 13.09.2019

DOI: $10.24075 /$ vrgmu.2019.058 
Parkinson's disease (PD) is a widespread neurological disorder most common in people over $>60$ years of age. It is estimated that at least 4 million individuals are affected worldwide. Today, the world's population is aging, and PD prevalence is expected to double by 2040 [1]. In the absence of curative treatment, the focus should be placed on researching the underlying molecular mechanisms of PD in animal models.

Typical motor symptoms of PD (bradykinesia, rigidity, resting tremors) are linked to the loss of dopaminergic neurons in substantia nigra pars compacta, nigrostriatal pathway degeneration and progressive neurotransmitter imbalance in the central nervous system (CNS) [2]. Non-motor features commonly include, but are not limited to, gastrointestinal disorders (constipation, etc.) striking long before the first motor symptoms are manifested [3]. Although the peripheral nervous system (PNS) is thought to be implicated in PDrelated gastrointestinal dysfunction, its trigger mechanisms and patterns of interaction between the CNS and PNS contributors to PD pathogenesis have not been completely elucidated.

The most significant molecular event leading to the loss of CNS neurons in patients with PD is misfolding of a small synaptic protein known as $\alpha$-synuclein [4]. Phosphorylated $\alpha$-synuclein aggregates observed in the neuronal cytoplasm are the primary constituents of Lewy bodies - the classic histopathological hallmarks of PD [2]. Interestingly, $\alpha$-synuclein pathology is not confined to cerebral neurons and is also seen in biopsy and autopsy specimens of the intramural intestinal plexus obtained from patients with PD This inspired a hypothesis that the disease begins in enteric plexuses and then spreads to other CNS structures via the vagus nerve [5]. Some findings suggest that the $\alpha$-synuclein cascade is triggered by certain environmental neurotoxins, such as heavy metals, pesticides and fungicides [6, 7]. For example, abnormal deposition of $\alpha$-synuclein can be induced by the powerful nonselective herbicide paraquat (1,1-dimethyl-4,4-bipyridinium dichloride). Paraquat is widely used for controlling noxious weeds that invade orchards, agricultural lands, coffee, tea and cocoa plantations, as well as for desiccating crops $[6,8,9]$. It bears structural resemblance to 1-methyl-4-phenylpyridinium (MPP+), the toxic metabolite of the well-known neurotoxin 1-methyl-4phenyl-1,2,3,6-tetrahydropyridine (MPTP). This makes paraquat suitable for modeling PD in animals. The toxic effect of paraquat is linked to the production of superoxide radicals; at the same time, the herbicide has low affinity for complex I of the mitochondrial electron transport chain.

Studies exploiting animal models of PD usually involve longterm exposure to paraquat administered systemically at $10 \mathrm{mg} / \mathrm{kg}$. Such regimens result in pronounced motor impairment in the animals and cause significant degeneration of dopamineproducing neurons in the substantia nigra [10]. This approach cannot be applied to obtain information about the early stages of PD or to assess non-motor symptoms that precede the onset of motor impairment. This study aimed to identify a complex of prodromal $\alpha$-synuclein-related pathological changes in rats exposed to small doses of paraquat and to compare it to the symptoms observed in the experimental animals in the early stage of induced PD.

\section{METHODS}

The study was conducted in male Wistar rats $(n=18)$ aged 3-3.5 months. The animals were kept under standard housing conditions (the 12/12 light/dark cycle) and had free access to food and water.

The animals were stratified into the main (paraquat) group $(n=10)$ and the control group $(n=8)$. Paraquat was dissolved in normal saline; $0.5 \mathrm{ml}(6 \mathrm{mg} / \mathrm{kg})$ of the obtained solution were administered to the animals from the main group on alternate days over the course of 4 weeks. The control group received an equal amount of normal saline. The next day after the last injection, the open field test (OPT) and the tapered beam walking test (BWT) were conducted to assess locomotor activity in the animals. The initial level of motor activity was measured in intact rats before the experiment. The open field arena was fabricated in the workshop of Research Institute of Neurology. It was a cube-shaped $75 \times 75 \times 40 \mathrm{~cm}$ box; its floor was divided into 25 equal squares. During the open-field test, we measured the distance each rat covered within 3 minutes. The beam-walking apparatus (Open science; Russia) was made of 2 overlaying $165-\mathrm{cm}$ long beams; the bottom beam was 10 to $5.5 \mathrm{~cm}$ in width; the lower beam, 6 to $1.5 \mathrm{~cm}$; the height was $2 \mathrm{~cm}$ for both beams. The enclosure at the narrow end of the walking bridge had a removable lid and a hole in the front panel to allow the animal inside. The apparatus was installed $70 \mathrm{~cm}$ above the floor. The rat traveled along the top beam from its far end towards the safe enclosure. For each animal, we counted the number of slips from the top beam throughout the entire route and the total number of steps made by each paw. The experiment was recorded using the Any-maze video-tracking system (Stoelting Inc.; USA).

Four brain tissue samples were selected from each group for further histopathologic examination. Briefly, the brain was removed and fixed in 4\% formalin. The samples were soaked in O.C.T. compound (TissueTek; USA); a series of 10- $\mu \mathrm{m}$ frontal sections was prepared in a Tissue-Tek Cryo3 Flex cryostat (Sakura Finetek; USA). The slides were immunofluorescently stained in order to determine tyrosine hydroxylase $(\mathrm{TH})$ and glial fibrillary acidic protein (GFAP) content in the tissue. TH is a protein marker for dopaminergic neurons, whereas GFAP levels are indicative of neurodegeneration in the nigrostriatal system. Cell nuclei were stained with DAPI. TH content was determined using polyclonal rabbit antibodies (1: 500, Sigma; Germany) and CF488-conjugated goat secondary antirabbit antibodies (1: 500, Sigma; Germany). GFAP levels were estimated using Cys3-conjugated antibodies (1: 80; Sigma). We examined 5 to 10 slides of each brain sample prepared from the tissue along the rostrocaudal axis at the level of the caudate nuclei and substantia nigra. The slides were studied under the Eclipse NiU fluorescence microscope (Nikon; Japan). The density of THpositive fibers was estimated in manually delineated regions at ×40 magnification in ImageJ (Wayne Rasband (NIH); USA); the mean fluorescence intensity of striatal tissue was corrected to background fluorescence.

Five to seven $\mathrm{cm}$-long regions of the jejunum were excised and dissected in the longitudinal plane following the mesentery course, washed in normal saline and spread out on the paraffin-coated bottom of Petri dishes. The specimens were fixed in $4 \%$ buffered formalin for $3 \mathrm{~h}$ and then washed in a phosphate buffer $(\mathrm{pH}=7.4)$. After that, the mucosal lining and the underlying submucosal layer were removed with ophthalmic forceps; the procedure was carried out under the Wild M7A stereomicroscope (Wild Heerbrugg; Germany). Fluorescence assays were performed on the obtained samples of the jejunum constituted of circular and longitudinal muscle fibers and the myenteric plexus. Primary antibodies to class III $\beta$-tubulin, TH and serin-129-phosphorylated $\alpha$-synuclein ( $\alpha$-Syn-p129) taken at $1: 250$ dilutions were used to identify nervous fibers in the myenteric plexus. Visualization of binding reactions was aided by secondary CF448-conjugated antibodies (Sigma; Germany) taken at a 1 : 100 dilution. The samples were examined and photographed using Nikon Eclipse NiU (Nikon; Japan) 
equipped with a Nikon DS-Qi digital camera (Nikon; Japan). Morphometric measurements were done in NIS Elements (Nikon; Japan) using images obtained at $\times 10$ magnification in at least 30-40 fields of view per animal. The mean fluorescence intensity and brightness (corrected to background staining) of the myenteric plexus fibers positive for class III $\beta$-tubulin and $\mathrm{TH}$ were measured in the NIS Elements software.

The obtained data were analyzed in Statistica 12 (StatSoft; USA); one-way ANOVA was followed by Fisher's exact test and Mann-Whitney $U$ test for post-hoc comparisons. The differences were considered significant at $p<0.05$.

\section{RESULTS}

Each experimental animal received a total of 12 paraquat injections. The initial distance travelled by the intact rats in the open field was $4.96 \pm 0.7 \mathrm{~m}$. The next day after the last injection, OFT revealed a decline in motor activity in the rats who had been exposed to paraquat, but the differences between the groups were insignificant (Fig. 1).

BWT demonstrated poor motor coordination in the rats from the main group manifesting itself as a statistically significant increase in the number of slips from the top beam made by left paws (Fig. 2). The number of slips was expressed as percentage from the total number of steps made by the corresponding limb.

The intensity of staining for $\mathrm{TH}$ was decreased in the substantia nigra of the animals who had been receiving paraquat injections; the histopathologic examination revealed damage to dopaminergic neurons. The most pronounced changes were observed in the striatum. The intensity of $\mathrm{TH}$-positive staining in striatal tissue was significantly lower in the main group than in the controls (Fig. 3). Low density of the detected dopaminergic fibers was predominantly observed in the dorsal aspect of the striatum. Another important finding was moderate gliosis (hypertrophy of GFAP-positive astrocyte projections).

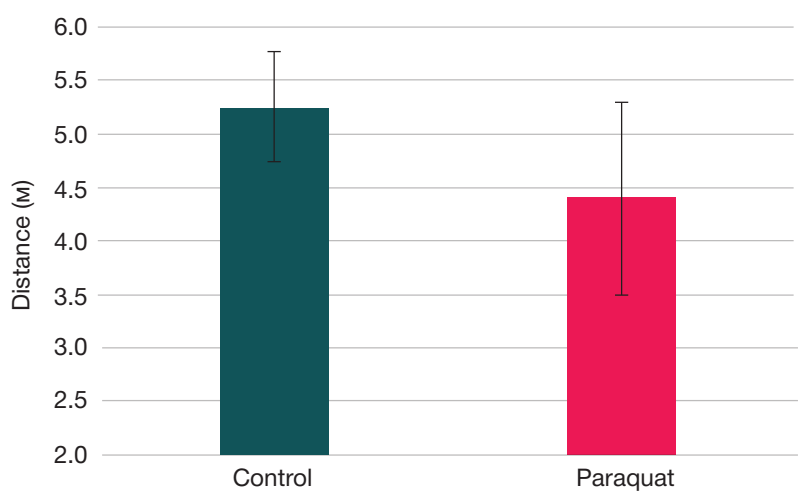

Fig. 1. The distance covered by the rats from the main and control groups in the open field test

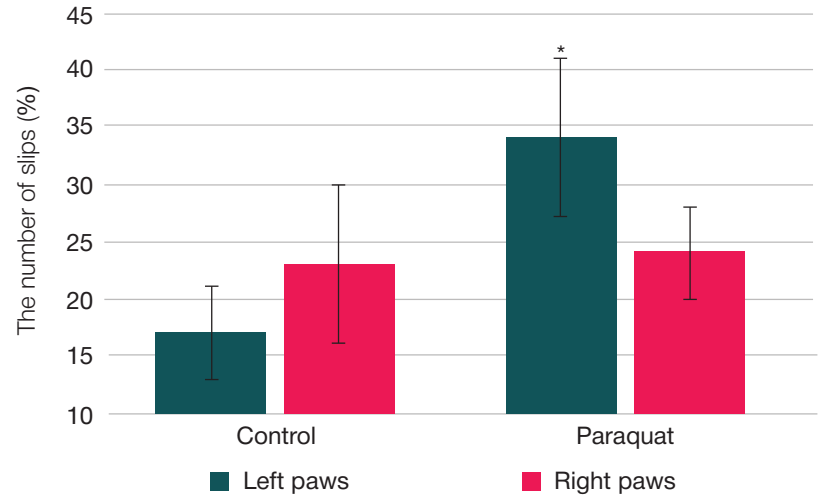

Fig. 2. The number of slips made by the animals in the main and control groups during the tapered beam walking test expressed as $\%$ from the total number of steps $(*-p=0.0445)$
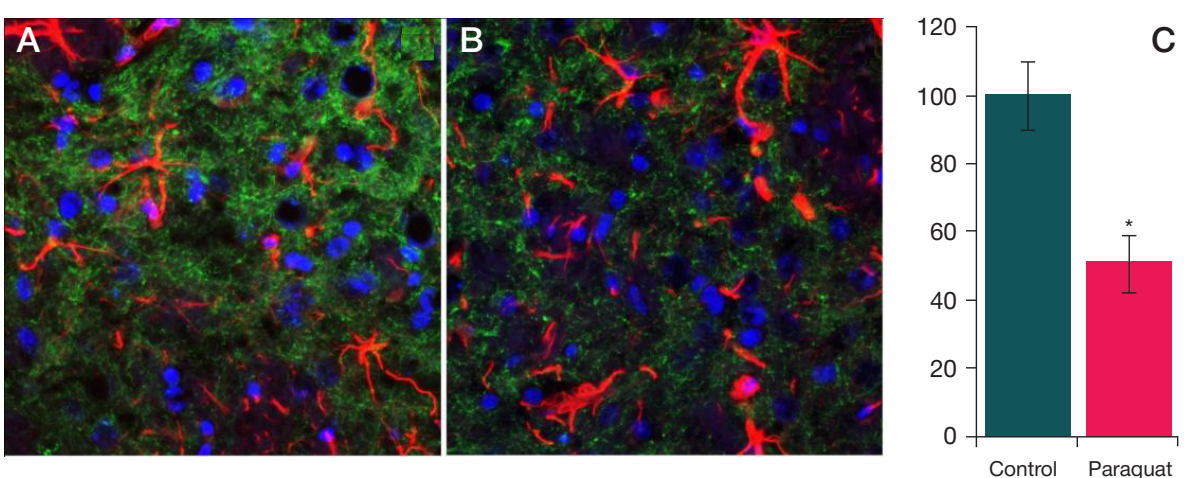

Fig. 3. Changes in the striatum of the experimental animals following long-term exposure to paraquat. Reduced density of TH-positive fibers and astrocyte hypertrophy in the striatum of the control (A) and the main (B) groups. Staining for TH is shown in green; staining for GFAP, in red; DAPI staining, in blue (immunofluorescent staining; magnification $\times 40)$. C. Changes in the intensity of $\mathrm{TH}$-positive staining expressed as $\%$ from the staining intensity observed in the intact controls $\left({ }^{*}-p=0.033\right.$; Mann-Whitney U) 
The intensities of staining for class III $\beta$-tubulin and TH were low in the myenteric plexus of the rat jejunum (Fig. 4). The levels of phosphorylated $\alpha$-synuclein ( $\alpha$-Syn-p129) were elevated in the cell bodies of myenteric neurons and in $\mathrm{TH}$-positive fibers (Fig. 5).

\section{DISCUSSION}

Paraquat holds great promise for PD modeling: some of its properties make paraquat-induced PD models suitable for exploring hypotheses of PD pathogenesis and testing novel drugs [11]. According to the literature, paraquat induces neuronal stress, stimulates production of free radicals in vitro and in vivo, causes elevation of $\alpha$-synuclein and tau, and promotes deposition of these proteins [8, 12, 13]. Despite the structural similarity between paraquat and $\mathrm{MPP}^{+}$[14], the two neurotoxins enter the brain via different pathways and have different mechanisms of action. Both of them are charged molecules; however, unlike $\mathrm{MPP}^{+}$, paraquat is delivered to the brain by a neutral amino acid transporter [15, 16]. Reports of paraquat effects on dopaminergic neurons are controversial.
Some authors describe motor dysfunction and death of dopaminergic neurons in rats and mice following systemic administration of paraquat $[14,10,17]$. Others report that experimental animals show no signs of motor deterioration in spite of nigrostriatal pathway degeneration [18, 14]. Although paraquat induces aggregation of $\alpha$-synuclein and other damage to dopamine-producing neurons of the substantia nigra, it does not have a pronounced effect on dopamine levels in the striatum, which might be due to the compensatory increase in $\mathrm{TH}$ activity in tis brain region [19].

In rats, paraquat-induced PD is usually modeled by exposing the animals to $10 \mathrm{mg} / \mathrm{kg}$ doses of the herbicide dissolved in normal saline. When administered intraperitoneally for 3 weeks, such doses cause selective death of dopaminergic neurons in the substantia nigra, poor motor coordination, reduced muscle tone and contractility [10]. Higher paraquat doses $(20-25 \mathrm{mg} / \mathrm{kg})$ are used to model severe damage to internal organs, such as kidneys or lungs [20]. However, our previous experience of exposing Wistar rats to $10 \mathrm{mg} / \mathrm{kg}$ paraquat doses for modeling PD was negative: by the time of the 5th injection, all experimental animals $(n=10)$ had been already dead. Necropsy revealed
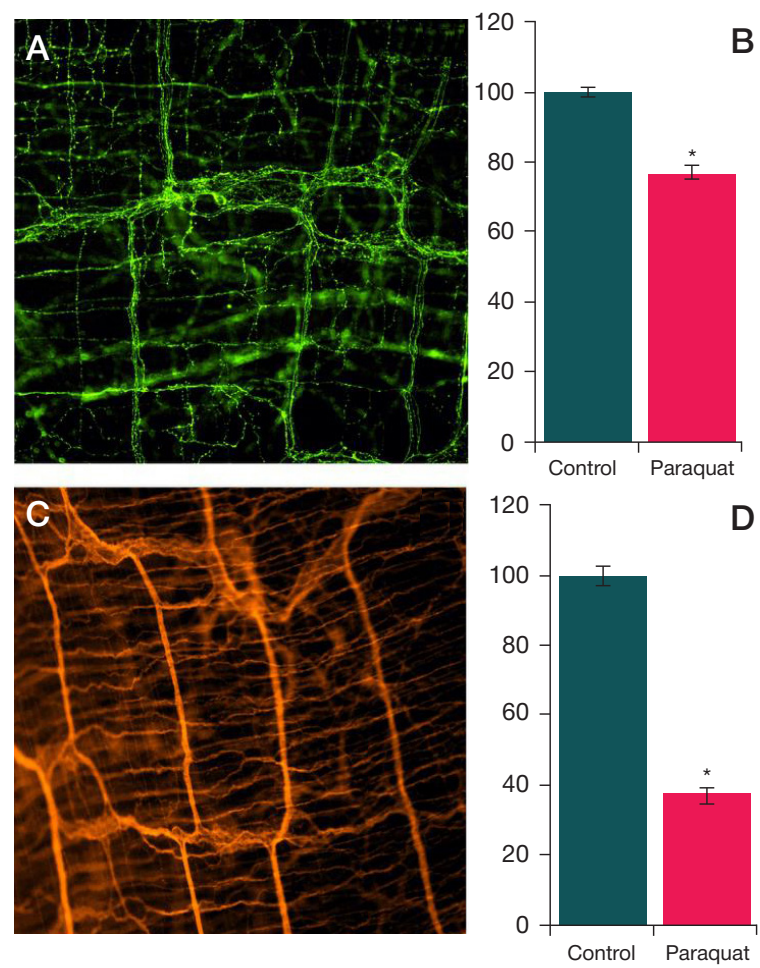

Fig. 4. Nervous fibers in the myenteric plexus of the rat jejunum containing TH $(\mathbf{A})$ and class III $\beta$-tubulin $(\mathbf{C})$ and changes in the fluorescence intensity of TH-positive (B) and class III $\beta$-tubulin-positive (D) fibers in the rats exposed to paraquat ( $\%$ from the intensity observed in the control group; magnification $\times 10$; ${ }^{*}-p=0.01$ )
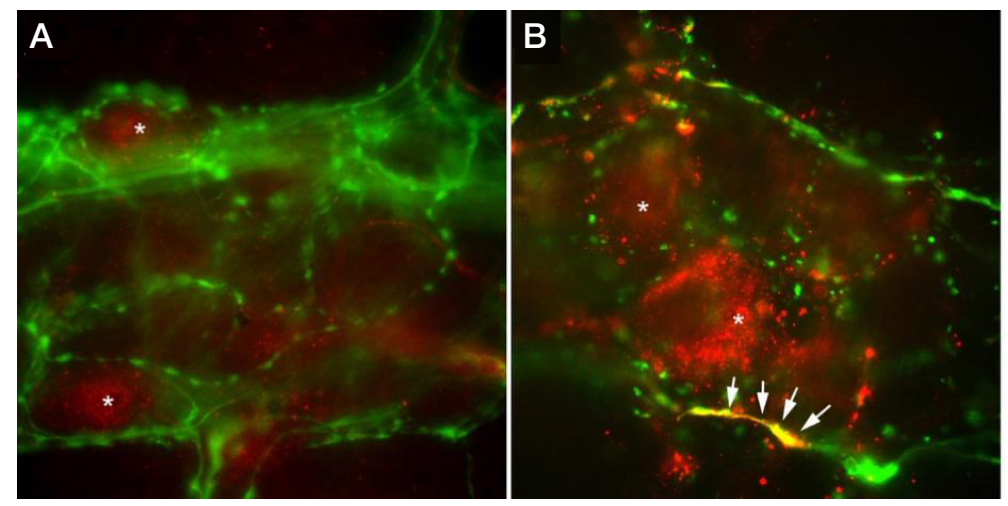

Fig. 5. Location of $\alpha$-Syn-p129 (shown in red) and TH (shown in green) in the myenteric plexus of the control group (A) and the rats exposed to paraquat (B). Synucleinpositive inclusions in $\mathrm{TH}$-positive nervous fibers are marked by arrows; neuronal bodies are marked by asterisks $\left({ }^{*}\right)($ magnification $\times 40$ ) 
typical paraquat-induced changes in the lungs, kidneys and other visceral organs [20]. In this study, we used $6 \mathrm{mg} / \mathrm{kg}$ paraquat doses, which allowed us to avoid animal death and to reproduce behavioral and morphological changes imitating the early manifestations of PD, including motor asymmetry. Asymmetry of motor symptoms (hypokinesia, resting tremors, etc.) is observed at the onset of the disease, but can become less pronounced over time as the disease progresses [21]. Motor asymmetry is instrumental in differentiating PD from other parkinsonian syndromes. At the same time, there have been few reports of asymmetrical damage to substantia nigra neurons in patients with $\mathrm{PD}[22,21]$. There is also only a scarce description of $\mathrm{PD}$ models that recreate motor asymmetry following systemic administration of neurotoxins. Our study fills this gap.

The intensity of staining in the myenteric fibers positive for class III $\beta$-tubulin was lower in the main group than in the controls. Although paraquat-induced disruption of microtubule assembly was described previously [23], our data on decreased staining intensity in the fibers positive for class III $\beta$-tubulin are inconsistent with the results obtained by some other researchers [6]. Perhaps, our findings do not so much indicate a decline in the absolute number of tubulin-positive nervous fibers, but instead point to a changed morphology of the enteric innervation, i.e. its exhaustion.

The studied brain samples were devoid of $\mathrm{TH}$-containing neuronal bodies; this suggests that $\mathrm{TH}$-positive nervous fibers found in the intermuscular plexus are sympathetic afferents, which is consistent with the reports by other researchers [24, 25]. The intensity of staining for $\mathrm{TH}$ was lower in the paraquat group than in the controls, which may indicate damage to sympathetic innervation in the small intestine and low $\mathrm{TH}$ content. Besides, weak staining intensity may reflect changes in fiber density or the functional state of the neurons.

Alpha-synuclein was detected in the peripheral nervous tissue fibers of both experimental and control groups. Under normal conditions, some $\alpha$-synuclein is present in neurons in the phosphorylated state [26]. In our study, the protein was diffusely distributed in the cell bodies of some myenteric plexus neurons. At the same time, the intensity of neuronal body staining was increased and $\mathrm{TH}$-containing fibers immunopositive for phosphorylated $\alpha$-synclein ( $\alpha$-Syn-p129) were thicker in the animals from the paraquat group. Morphological changes observed in nervous fibers and $\alpha$-Syn-p129 accumulation may be indicative of paraquatinduced production of protein aggregates typically seen in PD. Our findings coupled with previous reports of paraquatinduced $\alpha$-synuclein overexpression in the substantia nigra [6] emphasize the similarity of molecular pathogenesis of our PD model to the mechanisms of the actual disease.

The possible causes underlying paraquat-induced $\alpha$-synuclein accumulation in the enteric nervous system include production of reactive oxygen species and inflammation [27]. It was shown previously that inflammatory disorders of the intestine trigger accumulation of phosphorylated $\alpha$-synuclein in the myenteric plexus neurons of primates [28]. Imbalance between the phosphorylated and non-phosphorylated $\alpha$-synuclein pools is accompanied by the production of toxic protein fibrils and formation of its insoluble aggregates [29]. Pathologic accumulation of $\alpha$-synuclein in the fibers innervating the gastrointestinal tract and in the enteric plexus is typical of early PD stages and is regarded as a potential biomarker of the disease [30].

\section{CONCLUSIONS}

Systemic administration of $6 \mathrm{mg} / \mathrm{kg}$ doses of paraquat to rats induces behavioral and morphological changes similar to those seen in patients with early stages of $\mathrm{PD}$, one of them being $\alpha$-synuclein pathology in the peripheral nervous system that plays a key role in the pathogenesis of the disease. The proposed regimen is very promising for PD modeling and plays an important role in broadening our understanding of PD pathogenesis and developing novel therapeutic strategies.

\section{References}

1. Pringsheim T, Jette N, Frolkis A, Steeves TD. The prevalence of Parkinson's disease: a systematic review and meta-analysis. Mov Disord. 2014; (29): 1583-90.

2. Poewe W, Seppi K, Tanner CM, Halliday GM, Brundin P, Volkmann J, et al. Parkinson disease. Nat Rev Dis Primers. 2017; (3): 17013.

3. Chaudhuri K Ray, Titova N, editors. Nonmotor Parkinson's: The hidden face. International Review of Neurology. Vol. 133. Academic Press, 2017; 794 p.

4. Illarioshkin SN. Sovremennye predstavleniya ob etiologii bolezni Parkinsona. Nevrologicheskiy zhurnal. 2015; (4): 4-13.

5. Jellinger KA. Synuclein deposition and non-motor symptoms in Parkinson disease. J Neurol Sci. 2011; (310): 107-11.

6. Manning-Bog A, Mccormack A, Li J, Uversky V, Fink A, Di Monte D. The herbicide paraquat causes up-regulation and aggregation of alpha-synuclein in mice: paraquat and alpha-synuclein. J Biol Chem. 2002; (277): 1641-4.

7. Moretto A, Colosio C. Biochemical and toxicological evidence of neurological effects of pesticides: the example of Parkinson's disease. Neurotoxicology. 2011; (32): 383-91.

8. Fernagut PO, Hutson CB, Fleming SM, Tetreaut NA, Salcedo J, Masliah E, et al. Behavioral and histopathological consequences of paraquat intoxication in mice: Effects of alpha-synuclein overexpression. Synapse. 2007; (61): 991-1001.

9. Mak SK, McCormack AL, Manning-Bog AB, Cuervo AM, Di Monte DA. Lysosomal degradation of alpha-synuclein in vivo.
J Biol Chem. 2010; (285): 13621-9.

10. Fahimi MA. Shechab S, Nemmar A, Adem A, Dhanasekaran S, Hasan MY. Daily Subacute Paraquat Exposure Decreases Muscle Function and Substantia Nigra Dopamine Level Physiol Res. 2013; (62): 313-21.

11. Tieu K. A Guide to Neurotoxic Animal Models of Parkinson's Disease Cold Spring Harb Perspect Med. 2011; (1): a009316.

12. Bus JS, Gibson JE. Paraquat: Model for Oxidant-Initiated Toxicity. Environ Health Perspect. 1984; (55): 37-46.

13. Wills J, Credle J, Oaks AW, Duka V, Lee JH, Jones J, et al. Paraquat, but Not Maneb, Induces Synucleinopathy and Tauopathy in Striata of Mice through Inhibition of Proteasomal and Autophagic Pathways. PLoS ONE. 2012; 7(1): 1-12. DOI: 10.1371/journal. pone.0030745.

14. McCormack AL, Thiruchelvam M, Manning-Bog AB, Thiffault C, Langston JW, Cory-Slechta DA, et al. Environmental risk factors and Parkinson's disease: Selective degeneration of nigral dopaminergic neurons caused by the herbicide paraquat. Neurobiol Dis. 2002; 10: 119-27.

15. Shimizu K, Ohtaki K, Matsubara K, Aoyama K, Uezono T, Saito O, et al. Carrier-mediated processes in blood - brain barrier penetration and neural uptake of paraquat. Brain Res. 2001; (906): 135-42.

16. McCormack AL, Di Monte DA. Effects of L-dopa and other amino acids against paraquat-induced nigrostriatal degeneration. J Neurochem. 2003; (85): 82-6. 
17. Izumi Y, Ezumi M, Takada-Takatori Y, Akaike A, Kume T. Endogenous Dopamine Is Involved in the Herbicide Paraquat-Induced Dopaminergic Cell Death Toxicological Sciences. 2014; 139 (2): 466-78.

18. Thiruchelvam M, Brockel BJ, Richfield EK, Baggs RB, CorySlechta DA. Potentiated and preferential effects of combined paraquat and maneb on nigrostriatal dopamine systems: Environmental risk factors for Parkinson's disease? Brain Res. 2000; (873): 225-34.

19. Ossowska K, Wardas J, Smialowska M, Kuter K, Lenda T, Wieronska JM, et al. A slowly developing dysfunction of dopaminergic nigrostriatal neurons induced by long-term paraquat administration in rats: An animal model of pre-clinical stages of Parkinson's disease? Eur J Neurosci. 2005; (22): 1294-304.

20. Junboa Z, Yongtaob Y, Hongboa Li, Fenshuanga Z, Ruyuna L, Chun'aia $Y$. Experimental study of sucralfate intervention for paraquat poisoning in rats. Environmental Toxicology and Pharmacology. 2017; (53): 57-63.

21. Riederer $P$, Jellinger KA, Kolber P, Hipp G, Sian-Hulsmann J, Kruger R. Lateralisation in Parkinson disease. Cell Tissue Res. 2018; (373): 297. https://doi.org/10.1007/s00441-018-2832-z.

22. Djaldetti R, Ziv I, Melamed E. The mystery of motor asymmetry in Parkinson's disease. The Lancet Neurology. 2006; 5 (9): 796-802. DOI: 10.1016/s1474-4422(06)70549-X

23. Li WD, Zhao YZ, Chou IN. Paraquat-induced cytoskeletal injury in cultured cells. Toxicol Appl Pharmacol. 1987; 91 (1): 96-106.
24. Phillips RJ, Pairitz JC, Powley TL. Age-related neuronal loss in the submucosal plexus of the colon of Fischer 344 rats. Neurobiol Aging. 2007; 28 (7): 1124-37.

25. Phillips RJ, Hudson CN, Powley TL. Sympathetic axonopathies and hyperinnervation in the small intestine smooth muscle of aged Fischer 344 rats. Auton Neurosci. 2013; 179 (1-2): 108-121. DOI: 10.1016/j.autneu.2013.09.002.

26. Muntané G, Ferrer I, Martinez-Vicente M. $\alpha$-Synuclein phosphorylation and truncation are normal events in the adult human brain. Neuroscience. 2012; (200): 106-19. DOI: 10.1016/j. neuroscience.2011.10.042.

27. Toygar M, Aydin I, Agilli M, Aydin FN, Oztosun M, Gul H, et al. The relation between oxidative stress, inflammation, and neopterin in the paraquat-induced lung toxicity. Hum Exp Toxicol. 2015; 34 (2): 198-204. DOI: 10.1177/0960327114533808.

28. Resnikoff H, Metzger JM, Lopez M, Bondarenko V, Mejia A, Simmons HA, et al. Colonic inflammation affects myenteric alpha-synuclein in nonhuman primates. J Inflamm Res. 2019; (12): 113-26. DOI: 10.2147/JIR.S196552.

29. Zhang J, Li X, Li JD. The Roles of Post-translational Modifications on $\alpha$-Synuclein in the Pathogenesis of Parkinson's Diseases. Front Neurosci. 2019; (13): 381. DOI: 10.3389/fnins.2019.00381.

30. Yan F, Chen Y, Li M, Wang Y, Zhang W, Chen X, et al. Gastrointestinal nervous system $\alpha$-synuclein as a potential biomarker of Parkinson disease. Medicine (Baltimore). 2018; 97 (28): e11337. DOI:10.1097/ MD.0000000000011337.

\section{Литература}

1. Pringsheim T, Jette N, Frolkis A, Steeves TD. The prevalence of Parkinson's disease: a systematic review and meta-analysis. Mov Disord. 2014; (29): 1583-90.

2. Poewe W, Seppi K, Tanner CM, Halliday GM, Brundin P, Volkmann J, et al. Parkinson disease. Nat Rev Dis Primers. 2017; (3): 17013.

3. Chaudhuri K Ray, Titova N, editors. Nonmotor Parkinson's: The hidden face. International Review of Neurology. Vol. 133. Academic Press, 2017; 794 p.

4. Иллариошкин С. Н. Современные представления об этиологии болезни Паркинсона. Неврологический журнал. 2015; (4): 4-13.

5. Jellinger KA. Synuclein deposition and non-motor symptoms in Parkinson disease. J Neurol Sci. 2011; (310): 107-11.

6. Manning-Bog A, Mccormack A, Li J, Uversky V, Fink A, Di Monte D. The herbicide paraquat causes up-regulation and aggregation of alpha-synuclein in mice: paraquat and alpha-synuclein. J Biol Chem. 2002; (277): 1641-4.

7. Moretto A, Colosio C. Biochemical and toxicological evidence of neurological effects of pesticides: the example of Parkinson's disease. Neurotoxicology. 2011; (32): 383-91.

8. Fernagut PO, Hutson CB, Fleming SM, Tetreaut NA, Salcedo J, Masliah E, et al. Behavioral and histopathological consequences of paraquat intoxication in mice: Effects of alpha-synuclein overexpression. Synapse. 2007; (61): 991-1001.

9. Mak SK, McCormack AL, Manning-Bog AB, Cuervo AM, Di Monte DA. Lysosomal degradation of alpha-synuclein in vivo. $J$ Biol Chem. 2010; (285): 13621-9.

10. Fahimi MA. Shechab S, Nemmar A, Adem A, Dhanasekaran S, Hasan MY. Daily Subacute Paraquat Exposure Decreases Muscle Function and Substantia Nigra Dopamine Level Physiol Res. 2013; (62): 313-21.

11. Tieu K. A Guide to Neurotoxic Animal Models of Parkinson's Disease Cold Spring Harb Perspect Med. 2011; (1): a009316.

12. Bus JS, Gibson JE. Paraquat: Model for Oxidant-Initiated Toxicity. Environ Health Perspect. 1984; (55): 37-46.

13. Wills J, Credle J, Oaks AW, Duka V, Lee JH, Jones J. et al. Paraquat, but Not Maneb, Induces Synucleinopathy and Tauopathy in Striata of Mice through Inhibition of Proteasomal and Autophagic Pathways. PLoS ONE. 2012; 7(1): 1-12. DOI: 10.1371/journal. pone.0030745

14. McCormack AL, Thiruchelvam M, Manning-Bog AB, Thiffault C, Langston JW, Cory-Slechta DA, et al. Environmental risk factors and Parkinson's disease: Selective degeneration of nigral dopaminergic neurons caused by the herbicide paraquat.

Neurobiol Dis. 2002; (10): 119-27.

15. Shimizu K, Ohtaki K, Matsubara K, Aoyama K, Uezono T, Saito O, et al. Carrier-mediated processes in blood - brain barrier penetration and neural uptake of paraquat. Brain Res. 2001; (906): 135-42.

16. McCormack AL, Di Monte DA. Effects of L-dopa and other amino acids against paraquat-induced nigrostriatal degeneration. J Neurochem. 2003; (85): 82-6.

17. Izumi Y, Ezumi M, Takada-Takatori Y, Akaike A, Kume T. Endogenous Dopamine Is Involved in the Herbicide Paraquat-Induced Dopaminergic Cell Death Toxicological Sciences. 2014; 139 (2): 466-78.

18. Thiruchelvam M, Brockel BJ, Richfield EK, Baggs RB, CorySlechta DA. Potentiated and preferential effects of combined paraquat and maneb on nigrostriatal dopamine systems: Environmental risk factors for Parkinson's disease? Brain Res. 2000; (873): 225-34.

19. Ossowska K, Wardas J, Smialowska M, Kuter K, Lenda T, Wieronska JM, et al. A slowly developing dysfunction of dopaminergic nigrostriatal neurons induced by long-term paraquat administration in rats: An animal model of pre-clinical stages of Parkinson's disease? Eur J Neurosci. 2005; (22): 1294-304.

20. Junboa Z, Yongtaob Y, Hongboa Li, Fenshuanga Z, Ruyuna L, Chun'aia Y. Experimental study of sucralfate intervention for paraquat poisoning in rats. Environmental Toxicology and Pharmacology. 2017; (53): 57-63.

21. Riederer P, Jellinger KA, Kolber P, Hipp G, Sian-Hulsmann J, Kruger R. Lateralisation in Parkinson disease. Cell Tissue Res. 2018; (373): 297. https://doi.org/10.1007/s00441-018-2832-z.

22. Djaldetti R, Ziv I, Melamed E. The mystery of motor asymmetry in Parkinson's disease. The Lancet Neurology. 2006; 5 (9): 796-802. DOI: 10.1016/s1474-4422(06)70549-x

23. Li WD, Zhao YZ, Chou IN. Paraquat-induced cytoskeletal injury in cultured cells. Toxicol Appl Pharmacol. 1987; 91 (1): 96-106.

24. Phillips RJ, Pairitz JC, Powley TL. Age-related neuronal loss in the submucosal plexus of the colon of Fischer 344 rats. Neurobiol Aging. 2007; 28 (7): 1124-37.

25. Phillips RJ, Hudson CN, Powley TL. Sympathetic axonopathies and hyperinnervation in the small intestine smooth muscle of aged Fischer 344 rats. Auton Neurosci. 2013; 179 (1-2): 108-121. DOI: 10.1016/j.autneu.2013.09.002.

26. Muntané G, Ferrer I, Martinez-Vicente M. $\alpha$-Synuclein phosphorylation and truncation are normal events in the adult human brain. Neuroscience. 2012; (200): 106-19. DOI: 10.1016/j. 
neuroscience.2011.10.042.

27. Toygar M, Aydin I, Agilli M, Aydin FN, Oztosun M, Gul H, et al. The relation between oxidative stress, inflammation, and neopterin in the paraquat-induced lung toxicity. Hum Exp Toxicol. 2015; 34 (2): 198-204. DOI: 10.1177/0960327114533808.

28. Resnikoff H, Metzger JM, Lopez M, Bondarenko V, Mejia A, Simmons HA, et al. Colonic inflammation affects myenteric alpha-synuclein in nonhuman primates. J Inflamm Res. 2019;
(12): 113-26. DOI: 10.2147/JIR.S196552.

29. Zhang J, Li X, Li JD. The Roles of Post-translational Modifications on $\alpha$-Synuclein in the Pathogenesis of Parkinson's Diseases. Front Neurosci. 2019; (13): 381. DOI: 10.3389/fnins.2019.00381.

30. Yan F, Chen Y, Li M, Wang Y, Zhang W, Chen X, et al. Gastrointestinal nervous system $\alpha$-synuclein as a potential biomarker of Parkinson disease. Medicine (Baltimore). 2018; 97 (28): e11337. DOI:10.1097/ MD.0000000000011337. 